\title{
OB 80. LETNICI PROF. DR. DARKA RADINJE
}

Spodaj podpisani sem pred težko nalogo. Kako čim bolj celovito prikazati tako obsežno raziskovalno in pedagoško delo, ki ga je opravil prof. Radinja. Za res poglobljen in vsestransko ovrednoten pomen njegovega prispevka $\mathrm{v}$ geografiji, bo potrebno temeljito delo več boljši poznavalcev kot sem sam. Zato je tu le poskus predstavitve jubilantovega dolgoletnega strokovnega delovanja.

Profesor Radinja se je neizbrisno vpisal v zgodovino slovenske geografije s svojim raziskovanjem, njemu tako ljube slovenske pokrajine, skrbjo za natančen strokovni jezik, z oranjem ledine v preučevanju različnih geografskih vprašanj ter vzgojo mladih strokovnjakov, ki sedaj na univerzi in tudi drugod nadaljujejo njegovo delo.

Na takratni Prirodoslovno-matematično fakulteto je končal študij 1. 1952 C predmeta (fizika z meteorologijo), B predmeta (etnologija) in geografijo kot A predmet. Po diplomi se je zaposlil kot gimnazijski profesor. Leta 1959 se je vključil v takratni Geografski inštitut PMF, sedaj Oddelek za geografijo FF v Ljubljani. Leta 1960 je postal asistent in kasneje predavatelj za Matematično geografijo s kartografijo in Splošno fizično geografijo. Doktoriral je na Filozofski fakulteti leta 1965. Od leta 1966 je bil docent za fizično geografijo ter od leta 1972 izredni in od leta 1983 do upokojitve 1. 1996 redni prof. za fizično geografijo na Oddelku za geografijo FF v Ljubljani. Eno leto (1967/68) se je na moskovski in leningrajski univerzi izpopolnjeval v fizični geografiji (geomorfologija in hidrogeografija).

Morda lahko njegovo delo razdelimo na štiri dele:

1. didaktični

2. geomorfološki

3. hidrogeografski

4. varstveno okoljski

Ko je prišel na univerzo je začel predavati metodiko geografskega pouka. Povezanost s šolsko geografijo in potrebe šolskih geografov so ga vodile k izdajanju strokovnega glasila »Geografski obzornik«. Urejal ga je vrsto let, do sedaj pa je že izšlo 54 letnikov.

Kmalu pa je svoje znanstveno delovanje usmeril v geomorfologijo. V to obdobje njegovih raziskovanj spada zanimanje za problematiko fluvialne geomorfologije, nato pa kraške morfologije. Njegova morfološko-klimatska razlaga znižanja površja v usedlinah, neprepustnih za vodo, pod okoliške apnečanste planote zaradi pospešene kvartarne erozije je bil temelj obče kraške geomorfogeneze. Objavil je študije: Doberdobski Kras, Senožeško podolje, Vremska dolina. Omenim naj le razpravo: Zakrasevanje v Sloveniji v luči celotnega morfogemetskega razvoja. Preučeval je tudi Šentjernejski vršaj.

Zaradi spremenjenih razmer sledi bogato in dolgo obdobje, ko se je prof. Radinja usmeril v hidrogeografijo. Dolga leta je predaval ta predmet in preučeval iz geografskega stališča vode pri nas. Kot raziskovalec se je posvečal problematiki rečnih režimov (npr. Soče), poplav, izrabi vode za mline in oskrbe $\mathrm{z}$ vodo. Iz celotnega sklopa njegovega hidrogeografskega raziskovalnega dela še posebno izstopata dve tematiki, prva se nanaša na preučevanje rabe voda in druga na degradacijsko problematiko Blejskega jezera, ki ga je preučeval vrsto let. Vzporedno s tem so segale njegove meritve tudi na Bohinjsko jezero. V sklop sodi tudi 
preučevanje poplav in poplavišč s Sloveniji. Z navodili za raziskavo poplavnih območij in z vzorčno študijo Pšate je zasnoval skupinsko preučevanje poplavišč pri nas. Kot raziskovalec se je posvečal še problematiki izrabi vode za mline in oskrbe $z$ vodo.

Približno vzporedno z hidrogeografijo pa je prof. Radinja začel oblikovati predmet Varstvo geografskega okolja. To je četrto področje njegovega dela. Pri tem se je spopadal z začetnimi težavami, saj je bil v Sloveniji med prvimi, ki je uvedel, in se potem tudi dolga leta ukvarjal s problematiko voda in njihovim varstvom širom naše domovine. Sintetično delo o tem je razprava: Onesnaženost slovenskih rek in njene pokrajinske značilnosti.

$\mathrm{V}$ zadnjih letih dela na univerzi, pa se je v okviru varstva geografskega okolja usmeril v preučevanje ranljivosti tega okolja, še posebno v kmetijsko obremenjevanje pokrajinskega okolja. Pri tem delu se ni omejil le na posamezne dele Slovenije, temveč je razširil svoje delo na celo našo državo.

Za jubilantovo delo je značilno še to, da je s svojimi raziskavami vedno prispeval tudi $\mathrm{k}$ regionalni geografiji. $\mathrm{V}$ ta sklop njegovega dela sodi tudi njegovo zanimanje za naravne nesreče, pa naj bodo to usadi, zemeljski plazovi, žled.

$Z$ raziskovalnim delom je bilo povezano tudi njegovo pedagoško delo. S svojo jasnostjo in jedrnatostjo je slovel pri svojih študentih kot odličen predavatelj in cenjen profesor. Prof. Radinja je bil tudi mentor mnogim diplomantom, podiplomcem in doktorandom.

Sodeloval je z Zavodom SRS za šolstvo, kjer je bil član različnih komisij ter je za zavod izdelal več načrtov, poročil, mnenj in ocen. Sodeloval je tudi kot mentor pri gibanju »Znanost mladini« ter je med drugim vodil mladinske raziskovalne tabore v letih 1972, 1973, 1974 in 1975.

Prof. Radinja je na njemu lasten način kritično posegal tudi na področji teorije geografije in terminologije. Njegove razprave o teh vprašanjih so izšle v Geografskem vestniku in Geografskem obzorniku. S številnimi gesli iz hidrogeografije in varstva okolja ter njihovo razlago je sodeloval tudi pri »Geografskem terminološke slovarju «.

Prof. Radinja ima velike zasluge za razvoj fizične geografije, posebno hidrogeografije in predmeta varstvo geografskega okolja na ljubljanski univerzi. Njegov znanstveni opus obsega nad 200 bibliografskih enot, med katerimi je nad 80 tehtnih razprav. Za njegovo delo se mu je ZGDS oddolžila z najvišjim priznanjem, univerza pa z izvolitvijo v naziv zaslužni profesor.

Dr. Franc Lovrenčak 